\title{
Phytohormones Production and Phosphate Solubilization Capacities of Fluorescent Pseudomonas sp. Isolated from Shimla Dist. of Himachal Pradesh
}

\author{
Parul Sharma $^{1 *}$, Pankaj Prakash Verma ${ }^{2}$ and Mohinder Kaur ${ }^{1}$ \\ ${ }^{1}$ Department of Basic Science (Microbiology Section), Dr. Yashwant Singh Parmar University of \\ Horticulture and Forestry, Nauni, Solan-173230 (H.P), India \\ ${ }^{2}$ Department of Microbiology, Kurukshetra University, Kurukshetra-136119, Haryana, India \\ *Corresponding author
}

\section{A B S T R A C T}

\begin{tabular}{|c|}
\hline Keywords \\
\hline $\begin{array}{l}\text { Auxins, } \\
\text { Gibberellins, } \\
\text { Cytokinins, } \\
\text { Fluorescent } \\
\text { Pseudomonas sp., } \\
\text { Phosphate } \\
\text { solubilisation, } \\
\text { HCN. }\end{array}$ \\
\hline Article Info \\
\hline $\begin{array}{l}\text { Accepted: } \\
\text { 26 July } 2017 \\
\text { Available Online: } \\
\text { 10 September } 2017\end{array}$ \\
\hline
\end{tabular}

Fluorescent Pseudomonas species are the diverse group of soil microorganisms that are involved in plant growth enhancement through various direct or indirect mechanisms. The present study was conducted to investigate the phytohormone production and other plant growth promoting traits of indigenous fluorescent Pseudomonas sp. isolated from apple rhizosphere. All the eight isolates produced plant growth regulators viz., auxin, gibberellins and cytokinins in the range of $11-22 \mu \mathrm{g} / \mathrm{ml}, 25.92-43.32 \mu \mathrm{g} / \mathrm{ml}$ and 17-30 $\mu \mathrm{g} / \mathrm{ml}$ respectively. The maximum production of auxin $(22 \mu \mathrm{g} / \mathrm{ml})$ and gibberellins $(43.32$ $\mu \mathrm{g} / \mathrm{ml}$ ) was showed by isolate P7 whereas $\mathrm{M}$ and P11 isolates showed maximum production of cytokinins $(30 \mu \mathrm{g} / \mathrm{ml})$. The isolate $\mathrm{K}$ and P17 showed maximum $(46 \mu \mathrm{g} / \mathrm{ml})$ inorganic phosphate solubilization and maximum siderophore production of $43.32 \% \mathrm{SU}$ was showed by isolate P7. All the isolates showed ammonia production and only six isolates (viz., K, L, M, P3, P7 and P17) showed HCN production. Finally, these best selected fluorescent Pseudomonas isolates could be used for plant growth promotion and development of mixed bioformulation. The augmentation of such plant growth promoting fluorescent Pseudomonas in the ecosystems will ensure a healthy micro climate around the root environment by replacing chemical fertilizers.

\section{Introduction}

Soil microorganisms that colonize roots and promote plant growth represents a subset of rhizosphere bacteria called plant growth promoting rhizobacteria (PGPR). In recent years, the use of PGPR to promote plant growth had increased in various parts of world (Zahir et al., 2003). PGPR can affect plant growth by production and release of secondary metabolites, preventing deleterious effects of phytopathogenic organisms in the rhizosphere and/or facilitating the availability and uptake of certain nutrients from the root environment. The use of PGPR is steadily increasing in agriculture and offers an attractive way to replace chemical fertilizers, pesticides and supplements (Ashrafuzzaman et al., 2009).

Fluorescent Pseudomonas species are the diverse group of soil microorganisms able to synthesize different secondary metabolites with diverse biological activities. Plant hormones produced by Pseudomonas include auxins (indole acetic acid), cytokinins, 
ethylene 2, 3 butanediol and acetonin (Lambrecht et al., 2000). They are involved in the growth and development of plants. The production of plant growth regulators especially auxins induces additional root hair and lateral root formation hence thereby enhancing the plants ability to take up nutrients from soil and increase yield (Tien et al., 1979). The several species of Pseudomonas produce phytohormones or growth regulators that cause crops to have greater amounts of fine roots which have the effect of increasing the absorptive surface of plant roots for uptake of water and nutrients. The potential for auxin biosynthesis by rhizobacteria can be used as a tool for the screening of effective PGPR strains.

Many micro-organisms species producing phytohormones were able to form gibberellins and kinetin, either together with auxin or alone. Gibberellic acid and gibberellin like compounds were identified in cultures of Azotobacter chroococcum, A. baijerinckii, A. vinelandii, $A$. paspali, various pseudomonads and bacilli. Some strains of pseudomonads produced more types of auxins and gibberellins in large concentrations, together with kinetins (Azcon and Barea, 1975). Thus considering the importance of above mentioned topics, in the present study an attempt has been made to screen fluorescent Pseudomonas sp. for phytohormone production and phosphate solubilization that could induce plant growth and can be used for bioformulation development.

\section{Materials and Methods}

\section{Isolation of fluorescent Pseudomonas sp.}

Isolation of fluorescent Pseudomonas sp. was made from apple rhizhosphere of Shimla district of Himachal Pradesh (India). Isolation of fluorescent Pseudomonas sp. was made by following the serial dilutions and pour plate method using the specific King's B medium (King et al., 1954). The composition of the medium was $\left(\mathrm{g} / \mathrm{l}^{-1}\right)$ : Peptone, 20.0; $\mathrm{K}_{2} \mathrm{HPO}_{4}$, 1.5; $\mathrm{MgSO}_{4} .7 \mathrm{H}_{2} \mathrm{O}, 1.5$; Glycerol, $15.0 \mathrm{ml}$. Plates were incubated at $28^{0}+2^{0} \mathrm{C}$ for $48 \mathrm{hr}$. After incubation, well separated individual colonies with yellow green pigments were marked and detected by viewing under UV light.

The individual colonies were picked up with sterile loop and transferred to fresh King's B slants and the pure cultures so obtained were stored in refrigerator at $4^{0} \mathrm{C}$ for further use. These were again identified on the bases of morphological, biochemical and physiological tests and growth at optimum temperature i.e $4^{\circ} \mathrm{C}$ and $41^{\circ} \mathrm{C}$.

\section{Siderophores detection and quantification}

Siderophore production by fluorescent Pseudomonas isolates was detected by observing orange halos production on CAS agar plates after $72 \mathrm{hr}$ of growth. For quantitative estimation of siderophores, chrome azurol-S (CAS) liquid assay method (Schwyn and Neilands, 1987) was used. The siderophore content was expressed as percentage siderophore units (\% SU).

\section{Estimation of phosphate solubilization}

Phosphate solubilising activity was estimated on pikovskaya's agar plates with known amount of inert phosphorus $\left(\mathrm{Ca}_{3} \quad\left(\mathrm{PO}_{4}\right)_{2}\right)$ (Pikovskaya's, 1948). The composition of the medium was $\left(\mathrm{g} / \mathrm{l}^{-1}\right)$ : Glucose, 10.0; $\mathrm{Ca}_{3}\left(\mathrm{PO}_{4}\right)$, 5.0; $\quad\left(\mathrm{NH}_{4}\right)_{2} \mathrm{SO}_{4}, \quad 0.5 ; \quad \mathrm{MgSO}_{4} .7 \mathrm{H}_{2} \mathrm{O}, \quad 0.2 ;$ $\mathrm{MnSO}_{4}, 0.1 ; \mathrm{FeSO}_{4}, 0.0001$; Yeast extract, 0.5; Bromocresol purple, 0.1. Quantitative estimation of phosphate solubilization was done by spectrophotometric method (Dickman and Bray, 1940; Bray and Kurtz 1945; Olsen et al., 1954) and the results were expressed as $\mu \mathrm{g} / \mathrm{ml}$. 


\section{Detection of ammonia and HCN}

Fluorescent Pseudomonas isolates were tested for ammonia production according to Lata and Saxena (2003) and King's B medium amended with $0.44 \%$ Glycine was used for detection of hydrogen cyanide following the method of Bakker and Schippers (1987)

\section{Determination of auxins and produced by fluorescent Pseudomonas sp.}

Quantitative estimation of auxins was done by colorimetric method (Gorden and Weber, 1951) with slight modifications i.e. 2 to 3 drops of orthophosphoric acid was added to 2 $\mathrm{ml}$ supernatant and $4 \mathrm{ml}$ of salper reagent (1 $\mathrm{ml}$ of $0.5 \mathrm{M} \mathrm{FeCI}_{3}$ in $50 \mathrm{ml}$ of $30 \% \mathrm{HCIO}_{4}$ ). This mixture was incubated for 60 minutes in dark.

Absorbance was measured at $535 \mathrm{~nm}$. Concentration of auxins was estimated by preparing calibration curve using IAA as standard $(10-100 \mu \mathrm{g} / \mathrm{ml})$.

\section{Determination of gibberellins produced by fluorescent Pseudomonas sp.}

The gibberellins were estimated calorimetrically by the method of Holbrook et al., (1961). $15 \mathrm{ml}$ of supernatant, $2 \mathrm{ml}$ of zinc acetate reagent $(21.9 \mathrm{~g}$ zinc acetate $+1 \mathrm{ml}$ of glacial acetic acid and volume was made upto $100 \mathrm{ml}$ with distilled water) was added. $2 \mathrm{ml}$ of potassium ferrocyanide $(10.6 \%$ in distilled water) was added after 2 minutes and was centrifuged at $2000 \mathrm{rpm}$ for 15 minutes. To 5 $\mathrm{ml}$ of supernatant $5 \mathrm{ml}$ of 30 per cent $\mathrm{HCI}$ was added and mixture was incubated at $20^{\circ} \mathrm{C}$ for $75 \mathrm{~min}$.

Absorbance was read at $254 \mathrm{~nm}$ and concentration of gibberellins was calculated by preparing standard curve by using gibberellic acid as standard (10-100 $\mu \mathrm{g} / \mathrm{ml})$.

\section{Determination of cytokinins produced by fluorescent Pseudomonas sp.}

The production of cytokinins was estimated by radish cotyledons expansion bioassay test (Letham, 1971). The seeds of Raphanus sativus were germinated in total darkness for $48 \mathrm{hr}$. at $28^{\circ} \mathrm{C}$. The bioassay response (final weight-initial weight) was expressed as increase in weight. Concentration of cytokinins present in the extract was calculated by preparing standard curve by using kinetin as standard (10-100 $\mu \mathrm{g} / \mathrm{ml})$.

\section{Results and Discussion}

Eight bacterial isolates from apple rhizosphere were isolated. All isolates were Gram negative bacteria. These bacterial isolates were predominantly rod-shaped and fluorescent with irregular colonies though a few of them were circular (M and P17). All the bacterial isolates were large with an entire margin and produces yellowish to dark green pigmentation on King's B agar (Table 1). All the isolates viz., $\mathrm{K}, \mathrm{L}, \mathrm{M}, \mathrm{P} 3, \mathrm{P} 7, \mathrm{P} 11, \mathrm{P} 12$ and P17 exhibited green fluorescence under UV light. The versatile and predominant fluorescent Pseudomonas sp. was isolated which may attribute to specific selection of King's B medium employed for isolation. Several others hence supported the use of King's B medium for isolation of fluorescent Pseudomonas sp. (King et al., 1954).

The physiological and biochemical characteristics of all the isolates were given in table 2. All the identified isolates showed positive reactions for catalase and oxidase test confirming them to be Pseudomonas sp. (Bergey's Manual of Determinative Bacteriology, 1974). The isolates $\mathrm{K}, \mathrm{L}, \mathrm{P} 7$ and P12 were found to be positive for gelatin hydrolysis whereas $\mathrm{M}, \mathrm{P} 3, \mathrm{P} 11$ and $\mathrm{P} 17$ were not able to hydrolyse gelatin. Our study corroborate with Angayarkanni et al., (2005) 
who reported that $P$. fluorescens can dissolve solid gelatin into a liquid form with the presence of an enzyme responsible for gelatin hydrolysis in room temperature. Some species such as $P$. fluorescens strains are capable of denitrification and able to grow anaerobically in nitrate media. In our study six isolates $(\mathrm{K}$, P3, P7, P11, P12 and P17) were capable of denitrification however, negative responses were also identified for some Pseudomonas isolates such as for Tween 80 hydrolyses, growth at $4{ }^{\circ} \mathrm{C}$ and $41^{\circ} \mathrm{C}$.

All the isolates were able to grow at a temperature of $25^{\circ} \mathrm{C}$. Todar (2004) reported that incubation temperature around $30^{\circ} \mathrm{C}$ favours the growth of denitrifying biotypes of $P$. fluorescens, while temperatures above $37^{\circ} \mathrm{C}$ may be conducive for other Pseudomonas species. The results of this study indicate that the isolates may belong to $P$. fluorescens, Pseudomonas putida and Pseudomonas aeruginosa group. Reynolds (2004) also characterized and identified $P$. fluorescens on the bases of different biochemical tests like oxidase, catalase, gelatin hydrolysis, nitrate reduction and performing growth at different temperature.

All the fluorescent Pseudomonas isolates were screened for their ability to perform multiple plant growth promoting traits. All the isolates exhibited variation in production of different growth promoting activities. In our study, all the isolates of fluorescent Pseudomonas sp. isolated from apple rhizosphere showed production of siderophores and were able to solubilise phosphate. All the isolates were screened out for production of siderophores by qualitative and quantitative method. The results revealed that the maximum siderophore production was showed by isolate P7 (43.32\% SU) and the minimum by two isolates $\mathrm{M}$ and $\mathrm{P} 17$ (25.92 \% SU) (Table 3). Under plate assay method, the maximum siderophore production in terms of orange zone was also showed by
P7 (22 $\mathrm{mm})$ followed by seven isolates that showed siderophore production in the range of $11 \mathrm{~mm}$ to $15 \mathrm{~mm}$ diameter. Our results corroborate with Ganesan and Sekar (2012) who also reported the production of siderophores from fluorescent Pseudomonas sp. Fluorescent Pseudomonas produced extracellular siderophore which efficiently complex environmental iron, making it less available or unavailable to pathogen and native microflora (Dave and Dube, 2000).

The indigenous fluorescent Pseudomonas sp. was also screened out for production of phosphate solubilization by qualitative and quantitative method. All results were documented in table 3. The maximum production of phosphate solubilisation in terms of yellow zones ( $\mathrm{mm}$ diameter) on Pikovskaya's medium by plate assay method was showed by isolate $\mathrm{M}$ and P11 $(30 \mathrm{~mm})$ whereas all other isolates showed phosphate solubilization in the range of 17 to $27 \mathrm{~mm}$ diameter. The result also showed that maximum solubilization of inorganic tricalcium phosphate was showed by two isolates viz., $\mathrm{K}$ and P17 (46 $\mu \mathrm{g} / \mathrm{ml})$ followed by all other isolates which showed medium range of release of phosphorus i.e. 23 to 37 $\mu \mathrm{g} / \mathrm{ml}$. These results were supported by Verma and Kaur (2015) who isolated ten fluorescent Pseudomonas sp. from apple rhizosphere that had the ability to solubilise phosphate and the amount of $\mathrm{P}$ solubilized varied between all the isolates.

All the isolates of fluorescent Pseudomonas were screened for $\mathrm{HCN}$ and ammonia production. All the isolates were found to be positive for ammonia production whereas only six isolates viz., K, L, M, P3, P7 and P17 showed HCN production (Table 3 ). The isolate P11 and P12 did not showed HCN production. Verma et al., (2016) also reported the production of ammonia and $\mathrm{HCN}$ by fluorescent Pseudomonas sp. Microbial production of HCN has been suggested as an 
important antifungal feature to control root fungal pathogen as cyanide act as a general metabolic inhibitor to avoid predation or competition. The host plants are generally not harmfully affected by inoculation with $\mathrm{HCN}$ producing bacteria and rhizobacteria can operate as biological control agents (Ramette et al., 2003).

Table.1 Morphological characteristics of fluorescent

Pseudomonas sp. isolated from apple rhizosphere

\begin{tabular}{|c|c|c|c|c|c|}
\hline Isolates & Shape & Elevation & Edge & Opacity & Pigment \\
\hline K & Irregular & Flat & Entire & Transparent & Dark Green \\
\hline L & Irregular & Raised & Entire & Transparent & Yellowish \\
\hline M & Circular & Raised & Entire & Transparent & Yellowish \\
\hline P3 & Irregular & Flat & Entire & Transparent & Yellowish \\
\hline P7 & Irregular & Flat & Entire & Transparent & Yellowish \\
\hline P11 & Irregular & Flat & Entire & Transparent & Yellowish \\
\hline P12 & Irregular & Raised & Entire & Transparent & Yellowish \\
\hline P17 & Circular & Raised & Entire & Transparent & Yellowish \\
\hline
\end{tabular}

Table.2 Physiological and biochemical characteristics of fluorescent Pseudomonas sp. from apple rhizosphere

\begin{tabular}{|c|c|c|c|c|c|c|c|c|c|}
\hline Isolates & $\begin{array}{c}\text { Gelatin } \\
\text { Liquification }\end{array}$ & Denitrification & Catalase & $\begin{array}{c}\text { Tween 80 } \\
\text { hydrolysis }\end{array}$ & $\begin{array}{c}\text { Oxidase } \\
\text { test }\end{array}$ & $\mathbf{4}^{\circ} \mathbf{C}$ & $\mathbf{2 5}^{\circ} \mathbf{C}$ & $\mathbf{4 1}^{\circ} \mathbf{C}$ & Lecitinase \\
\hline K & + & + & + & + & + & - & + & + & + \\
\hline L & + & - & + & - & + & + & + & - & - \\
\hline M & - & - & + & - & + & + & + & - & - \\
\hline P3 & - & + & + & + & + & + & + & - & - \\
\hline P7 & + & + & + & + & + & + & + & + & - \\
\hline P11 & - & + & + & - & + & + & + & + & - \\
\hline P12 & + & + & + & - & + & + & + & + & - \\
\hline P17 & - & + & + & - & + & + & + & + & - \\
\hline
\end{tabular}

Table.3 Characterization of fluorescent Pseudomonas sp. for plant growth promoting traits

\begin{tabular}{|c|c|c|c|c|c|c|}
\hline \multirow[t]{3}{*}{ Isolates } & \multicolumn{2}{|c|}{ Siderophore } & \multicolumn{2}{|c|}{ Phosphate Solubilization } & $\mathbf{H C N}$ & Ammonia \\
\hline & Qualitative & Quantitative & Qualitative & Quantitative & \multicolumn{2}{|c|}{$\begin{array}{c}\text { Change of color } \\
\text { (yellow to brown) }\end{array}$} \\
\hline & $\begin{array}{c}\text { Plate } \\
\text { (mm dia) }\end{array}$ & $\% \mathrm{SU}^{*}$ & $\begin{array}{c}\text { Plate } \\
\text { (mm dia) }\end{array}$ & $(\mathrm{Pi} \mu \mathrm{g} / \mathrm{ml}) * *$ & $\begin{array}{l}\text { Paper } \\
\text { strip }\end{array}$ & Culture broth \\
\hline $\mathrm{K}$ & 11 & 33.33 & 19 & 46 & ++ & ++++ \\
\hline $\mathrm{L}$ & 12 & 33.33 & 17 & 23 & + & +++ \\
\hline $\mathrm{M}$ & 13 & 25.92 & 30 & 35 & + & +++ \\
\hline P3 & 15 & 37.03 & 25 & 37 & +++ & ++ \\
\hline $\mathrm{P} 7$ & 22 & 43.32 & 22 & 26 & +++ & +++ \\
\hline P11 & 13 & 33.33 & 30 & 45 & - & + \\
\hline P12 & 12 & 40.74 & 27 & 35 & - & + \\
\hline $\mathrm{P} 17$ & 13 & 25.92 & 19 & 46 & +++ & +++ \\
\hline
\end{tabular}

*The siderophore unit (\% SU) expressed as percent reduction in blue color of chrome azurol-S as compared to reference i.e. \% SU= $(\mathrm{Ar}-\mathrm{As}) / \mathrm{Ar} \times 100$; where, $\mathrm{Ar}=$ Absorbance of reference solution at $630 \mathrm{~nm}$; As = Absorbance of test solution at $630 \mathrm{~nm}$

**Phosphate solubilizing activity expressed in terms of tricalcium phosphate solubilization which in turn represents $\mu \mathrm{g} / \mathrm{ml}$ of soluble inorganic phosphate $(\mathrm{Pi})$ in supernatant as calibrated from the standard curve of $\mathrm{KH}_{2} \mathrm{PO}_{4}(10-100$ $\mu \mathrm{g} / \mathrm{ml})$. 
Table.4 Screening of Pseudomonas sp. for the production of plant growth regulators

\begin{tabular}{|c|c|c|c|}
\hline \multirow{2}{*}{ Isolates } & \multicolumn{3}{|c|}{ Plant growth regulators $(\boldsymbol{\mu g} / \mathbf{m l})$} \\
\cline { 2 - 4 } & Auxin* & Gibberellins** & Cytokinins**** \\
\hline K & 11 & 33.33 & 19 \\
\hline L & 12 & 33.33 & 17 \\
\hline M & 13 & 25.92 & 30 \\
\hline P3 & 15 & 37.03 & 25 \\
\hline P7 & 22 & 43.32 & 22 \\
\hline P11 & 13 & 33.33 & 30 \\
\hline P12 & 12 & 40.74 & 27 \\
\hline P17 & 13 & 25.92 & 19 \\
\hline
\end{tabular}

Extracellular production of plant growth regulators i.e. Auxins*, Gibberellins** and Cytokinins*** expressed in terms of concentration $(\mu \mathrm{g} / \mathrm{ml})$ in $72 \mathrm{~h}$ old supernatant as calibrated from the standard curve of indole acetic acid (IAA); $10-100(\mu \mathrm{g} / \mathrm{ml})$, gibberellic acid $\left(\mathrm{GA}_{3}\right) ; 100-1000(\mu \mathrm{g} / \mathrm{ml})$, kinetin;10-100 $(\mu \mathrm{g} / \mathrm{ml})$

All the fluorescent Pseudomonas sp. was characterized for the production of plant growth regulators viz., auxins, gibberellins and cytokinins by their specific spectrophotometric and bioassay methods. The results showed that all the isolates of Pseudomonas sp. produced plant growth regulators whereas the level of production of plant growth regulators varies among all the bacterial isolates (Table 4). The isolate P7 produced maximum amount of auxin viz., 22 $\mu \mathrm{g} / \mathrm{ml}$, whereas all the other isolates produced auxins between 11 and $15 \mu \mathrm{g} / \mathrm{ml}$ (Table 4). Similar results were also observed by Verma et al., (2016) in which all the screened fluorescent Pseudomonas sp. produced auxin in concentration of 2.0 to $14.0 \mu \mathrm{g} / \mathrm{ml}$. Similarly Sharma et al., (2014) also reported production of auxin by fluorescent Pseudomonas sp. which varied among all the isolates. All the eight isolates of fluorescent Pseudomonas sp. showed the production of gibberellins. The gibberellins production was found in the range of $25.92-43.32 \mu \mathrm{g} / \mathrm{ml}$ (Table 4). The maximum gibberellins production was observed in P7 $(43.32 \mu \mathrm{g} / \mathrm{ml})$ followed by P12 $(40.74 \mu \mathrm{g} / \mathrm{ml})$. All the isolates also produced cytokinins in the range of $17-30 \mu \mathrm{g} / \mathrm{ml}$ (Table 4). The minimum production of auxin was showed by isolate $\mathrm{L}$ (17 $\mu \mathrm{g} / \mathrm{ml})$. Thakur et al., (2013) also observed the production of gibberellins and cytokinins by fluorescent Pseudomonas isolates in the range 15.20 to $179.48 \mu \mathrm{g} / \mathrm{ml}$ and 51.20 to $179.48 \mu \mathrm{g} / \mathrm{ml}$ respectively. This study is assumed to be important as the agriculturally beneficial fluorescent Pseudomonas sp. could be one of the potential candidates in the development of biofertilizer and these isolates could be explored further under field condition.

\section{References}

Angayarkanni, T., Kamalakannan, A., Santhini, E. and Pradeepa, D. 2005. Identification of biochemical markers for the selection of Pseudomonas fluorescens against Pythium spp. In: Asian Conference on Emerging Trends in Plant-Microbe Interactions. Univ. Madras, Chennai. Pp. 295-303.

Ashrafuzzaman, M., Hossen Farid Akhtar, Ismail M. Razi, Hoque Md. Anamul, Islam M. Zahurul, Shahidullah and Meon Sariah. 2009. Efficiency of plant growth-promoting rhizobacteria (PGPR) for the enhancement of rice growth. African Journal of Biotechnology. 8(7): 1247-1252.

Azcon, R., and Barea, J.M. 1975. Synthesis of auxins, gibberellins and cytokinins by Azotobacter vinelandii and Azotobacter beijerinckii related to effects produced 
on tomato plants. Plants and Soil. 43: 609-619.

Bakker, A.W., and Schippers, B. 1987. Microbial cyanide production in the rhizosphere in relation to potato yield reduction and Pseudomanas sp. mediated plant growth stimulation. Soil Biology and Biochemistry, 19: 451-457.

Bergey, D.H., Buchanan, R.E. and Gibbons, N.E. 1974. Part 7: Gram negative aerobic rods and cocci: Pseudomonas fluorescens In: Bergey's Manual of Determinative Bacteriology 8th Edition. Baltimore: The Williams \& Wilkins Company. Pp. 221-223.

Bray, R.H., and Kurtz, L.T. 1945. Determination of total organic available forms of phosphorus in soil. Soil Science. 23: 343-353.

Dave, B.P., and Dube, H.C. 2000. Chemical characterization of fungal siderophores. Indian Journal of Experimental Biology. 38: 56-62.

Dickman, S.R., and Bray, R.H. 1940. Colorimetric determination of phosphate. Indus and Engineering chemical Analytical Edition 12: 660665.

Ganesan, S., and Sekar, R. 2012. Fluorescent Pseudomonas as plant growth promoting rhizobacteria and biocontrol agents in groundnut crop (Arachis hypogaea L.). International Journal of Applied BioResearch. 12: 1-6.

Gordon, S.A., and Weber, R.P. 1951. Colorimetric estimation of indole acetic acid. Plant Physiology. 26: 192-195.

Holbrook, A.A., Edge, W.J.W. and Bailey, F. 1961. Spectrophotometric method for determination of gibberellic acid in gibberellin. ACS: Washington. pp. 159167.

King, E.O., Ward, M.K. and Raney, D.E. 1954. Two simple media for the demonstration of pyocyanin and fluoresccein. Journal of Laboratory and
Clinical Medicine. 44: 301-307.

Lambrecht, M., Okon, Y., VandeBroek, A. and Vandeleyden, J. 2000. Indole-3acetic acid: a reciprocal signaling molecule in bacteria plant interaction. Trends Microbial. 8: 298-300.

Lata and Saxena, A.K. 2003. Characterization of plant growth promoting rhizobacteria In: Training manual on biofertilizers technology (Eds.) Saxena, A.K. IARI: Delhi. Pp. 24-25.

Letham, 1971. Regulator of cell division in plant tissue. XII. A cy6tokinin bioassay using excised radish cotyledons. Physiologia Plantarum. 25: 391-396.

Olsen, S.R., Cole, C.V., Whatanable, F.S. and Dean, L.A. 1954. Estimation of available phosphorus by extraction with sodium bicarbonate. US Department of Agriculture. 939 p.

Pikovsakaya, R.E., 1948. Mobilization of phosphorus in soil in connection with vital activity of some microbial species. Microbiologia. 17: 362-370.

Ramette, A., Moënne Loccoz, Y. and Défago, G. 2003. Prevalence of fluorescent pseudomonads producing antifungal phloroglucinols and/or hydrogen cyanide in soils naturally suppressive or conducive to tobacco black root rot. FEMS Microbiol Ecol. 44: 35-43.

Reynolds, J., 2004. Lab procedures manual: biochemical tests. Richland College. http://www.rlc. deccd.edu/ mathsci/Reynolds /micro/lab_manual/TOC.html.

Schwyan, B., and Neilands, J.B. 1987. Universal chemical assay for the detection and determination of siderophore. Analytic Biochemistry. 28(8): 751-759.

Sharma, S., Verma P.P. and Kaur, M. 2014. Isolation, purification and estimation of IAA from Pseudomonas sp. using HPLC. Journal of Pure and Applied Microbiology. 8(4): 3203-3208. 
Thakur, D., Kaur, M. and Shyam, V. 2013. Management of replant problem by the production of plant growth regulators and phosphate solubilising potential of fluorescent Pseudomonas sp. isolated from the normal and replant sites of apple and pear. Indian Streams Research Journal. 3(4): 1-8.

Tien, T.M., Gaskins and Gubble, D.H. 1979. Plant growth substance by Azospirillum brazilance and their effect on growth of pearl millet. Applied Environmental Microbiology. 37: 1016-1024.

Todar, K., Pseudomonas and related bacteria. Todar's online text book of bacteriology.2004

http://textbookofbacteriology.net/Pseud omonas. etc.html.
Verma, P.P., and Kaur, M. 2015. Characterization of mineral phosphate solubilizing activity of fluorescent Pseudomonas sp. isolated from rhizosphere of apple. Trends in Biosciences. 8(23): 6600-6604.

Verma, P.P., Thakur, S. and Kaur, M. 2016. Antagonism of Pseudomonas putida against Dematophora nectarix a major apple plant pathogen and its potential use as a bio-stimulant. Journal of Pure and Applied Microbiology. 10(4): 27172726.

Zahir, A., Arshad, A. and Frankenberger, W.T. 2003. Plant growth promoting rhizobacteria: applications and perspectives in agriculture. Advances in Agronomy. 81: 97-168.

\section{How to cite this article:}

Parul Sharma, Pankaj Prakash Verma and Mohinder Kaur. 2017. Phytohormones Production and Phosphate Solubilization Capacities of Fluorescent Pseudomonas sp. Isolated from Shimla Dist. of Himachal Pradesh. Int.J.Curr.Microbiol.App.Sci. 6(9): 2447-2454. doi: https://doi.org/10.20546/ijcmas.2017.609.301 